\begin{tabular}{|c|c|c|}
\hline$\underset{P \cup B L I C A T I O N}{\operatorname{NF}{ }^{*} \mathrm{AIN}}$ & $\begin{array}{l}\text { International Journal of Advanced Engineering, Management and } \\
\text { Science (IJAEMS) } \\
\text { ISSN: 2454-1311 } \\
\text { Vol-7, Issue-3; Mar, } 2021 \\
\text { Journal Home Page Available: } \underline{\text { https://ijaems.com/ }} \\
\text { Journal DOI: } \underline{\text { https://dx.doi.org/10.22161/ijaems }} \\
\text { Article DOI: https://dx.doi.org/10.22161/ijaems.73.1 }\end{array}$ & (1) \\
\hline
\end{tabular}

\title{
Effect of COVID-19 outbreak towards banking and finance industry
}

\author{
Nashirah Abu Bakar ${ }^{1}$, Sofian Rosbi ${ }^{2}$
}

${ }^{1}$ Islamic Business School, College of Business, University Utara Malaysia,06010 Sintok, Kedah, Malaysia ${ }^{2}$ Facuty of Applied and Human Sciences, University Malaysia Perlis, 01000 Kangar, Perlis, Malaysia

Received: 04 Dec 2020; Received in revised form: 28 Jan 2021; Accepted: 22 Feb 2021; Available online: 09 Mar 2021 (C)2021 The Author(s). Published by Infogain Publication. This is an open access article under the CC BY license (https://creativecommons.org/licenses/by/4.0/).

\begin{abstract}
The coronavirus disease COVID-19 spreading throughout the worldwide with the total confirmed affected cases is 96,658,420, including 2,092,062 deaths, reported to WHO on $23^{\text {rd }}$ January 2021. These numbers proved that COVID-19 become most affected virus in year of 2021. This virus affected all market segments of economic activities including banking and finance industry. The objective of this study is to evaluate the economic impact of COVID-19 outbreak towards banking and finance industry. This study selected two market indices (S\&P500 and KLCI) for analyzing economic condition in equity market. Then, this study selected three banking institution for validating the finding for economic condition during outbreak of COVID-19. Result shows outbreak of COVID-19 give negative impact towards economic condition for banking and finance industry. The findings of this study will help practitioners and government body in developing finance policy to combating the current economic situation. Further study can be extending to analyzing the effectiveness monetary policy towards recovery of finance situation after COVID-19 outbreak. Furthermore, the finding of this study also will help banking institutions to develop more customer-friendly interest rate in overcoming this economic situation of COVID-19.
\end{abstract}

Keywords-COVID-19, Banking, Finance, Market index, Coronavirus disease.

\section{INTRODUCTION}

Financial intermediary is important body in the relationship between savers and borrowers. The example of financial intermediary is banking institution, insurance company and other institutions. The main function of financial intermediary is to channel savings into investments activities for generate a profit. The main objective of investments is to generate a high return and reduce a risk. Therefore, Bursa Malaysia must show a good reputation in managing portfolio investments in order to achieve the objective of investment.

Investment is the complex process involving decision making regarding the possible expected rate of return ( $\mathrm{Abu}$ Bakar and Rosbi, 2018a). Many studies investigate the performance of investment portfolio (Abu Bakar and
Rosbi, 2017a; Abu Bakar and Rosbi, 2019a) indicated the good performance of investment portfolio in Malaysia market. Kighir, et al., (2015) examines the Malaysia nonfinancial firms consider current earnings more important than current cash flow while making dividends payout decisions. In Malaysia, Bursa Malaysia is the stock exchange market that led the portfolio investment in Malaysia and globally. Bursa Malaysia comprise two types of market known as main market and ACE market. The index used in Bursa Malaysia known as KLCI index (Kuala Lumpur Composite Index) that comprise 30 largest companies listed on the Main Board of Bursa Malaysia. Several studies that focuses on the performance of companies listed on the Bursa Malaysia show that this stock market is a good platform for capital growth in short- 
term and long-term investment (Abu Bakar and Rosbi, 2019b).

Even there are many studies indicated a good performance of Bursa Malaysia, but the problem nowadays is due to the COVID-19 pandemic happened since year 2019. Many industries were affected by COVID-19 pandemic such as tourism industry, manufacturing industry and others sector. Therefore, this study was investigated the effect of COVID-19 outbreak toward banking and finance industry by selected two market indices that are S\&P500 and KLCI index. Furthermore, this study was analyzed three banks in Malaysia that are CIMB Bank Berhad, Malayan Banking Berhad and Public Bank Berhad.

\section{LITERATURE REVIEW}

The rapid growth of investment portfolio in Malaysia was driven by efficiency of Bursa Malaysia as a platform of capital market growth. Many studies examine the performance of Malaysian exchange market (Abu Bakar and Rosbi, 2017b). As suggested by Abu Bakar and Rosbi (2018b) stock market is one of the most important indicators on how the economic are moving up. Positive increment of dynamic movement for the share price indicates a good performance of stock market in Malaysia. Thus, the stability of economic is depending on the good performance of companies listed on the stock market. Besides that, the diversification of investment is one of the strategic in generating a maximum return and minimize a risk (Abu Bakar and Rosbi, 2019d).

Others study like Tee (2017) suggested that regulators should increase their surveillance and monitoring effort into Malaysian companies. In addition, Malaysian companies should be transparent in their corporate dealings and auditors should strengthen their audit efforts in order to provide more reliable financial information.

While, Zainudin, et al., (2018), analyses the relationship between stock price volatility and dividend policy companies listed on Bursa Malaysia indicate that dividend policy is a strong predictor of stock price volatility of industrial products companies in Malaysia. Michelfelder and Pandya (2005) found that emerging markets have higher volatility yet lower persistence of shocks than in mature markets. Study by Abu Bakar and Rosbi (2019c) regarding the performance of Bursa Malaysia suggested that the KLCI can be a good indicator in developing a new insight of Malaysian capital market growth globally.

Moreover, Abu Bakar and Rosbi (2020) highlight that the COVID-19 give a bad impact on the performance of equity market in Malaysia and suggested to develop a solution in stabilizing economic situation in COVID-19 outbreak. In the same time, investors need to monitor the equity market in order to develop a good combination of investment portfolio to gain better return and reducing loss.

\section{IMPACT OF CORONAVIRUS DISEASE TOWARDS MARKET INDEX OF S\&P 500 AND KLCI}

This paper evaluated the economic condition during outbreak of coronavirus disease COVID-19. The COVID19 disease spreading easily between humans through close contact. The virus that causes COVID-19 most commonly spreads between people who are in close contact with one another within about one meter. It spreads through respiratory droplets or small particles, such as those in aerosols, produced when an infected person coughs, sneezes, sings, talks, or breathes. The coronavirus that causes COVID-19 is primarily transmitted through droplets containing virus, or through viral particles that float in the air.

The COVID-19 pandemic represents an unprecedented disruption to the global economy and world trade. This study evaluated two market indexes to analyze the impact of COVID-19 towards economic situation. Figure 1 shows the dynamic behavior of market index for S\&P500. The observation periods selected from trading days in February 2020 until April 2020. This period selected because this time frame shows the significant effect of COVID-19 outbreak towards economic activities.

First observation of market value S\&P 500 is 3248.92 on $3^{\text {rd }}$ February 2020. The maximum value of market index S\&P 500 is 3386.15 on $12^{\text {th }}$ observation period $\left(19^{\text {th }}\right.$ February 2020). The minimum value of S\&P 500 is 2237.40 on $35^{\text {th }}$ observation period ( $23^{\text {rd }}$ March 2020). The significant drop in S\&P 500 market index indicates COVID-19 outbreak give negative effect towards economic development.

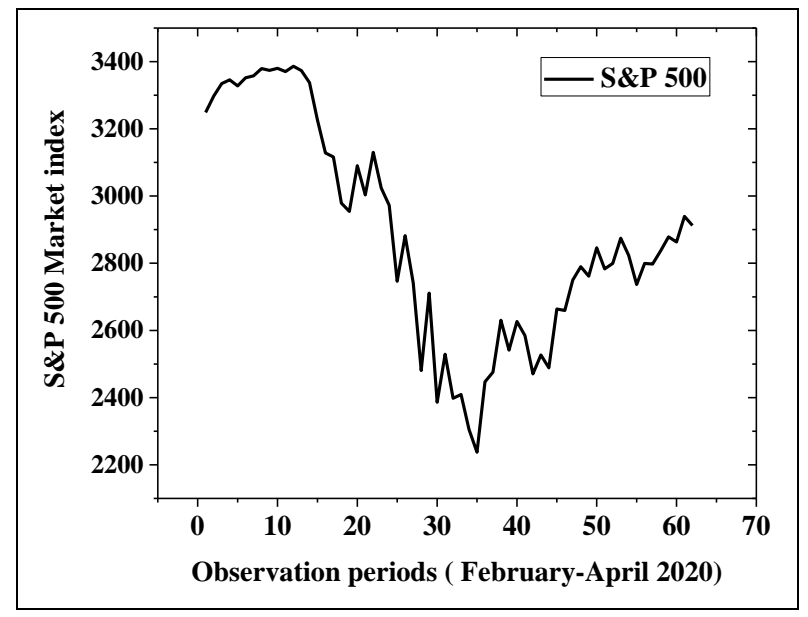

Fig. 1: Dynamic behavior of $S \& P 500$ market index 
Next, this study evaluated the dynamic behavior of Kuala Lumpur Composite Index (KLCI) as shown in Figure 2. The observation periods involving three months starting from February 2020 until April 2020. This period is important to analyze in evaluating the effect of COVID-19 outbreak toward economy activities because this is the period where the first wave of infection in global level.

Figure 2 shows the price movement of Kuala Lumpur Composite Index for 64 daily trading of observation periods. The maximum value of KLCI is 1554.49 on $5^{\text {th }}$ observation ( $7^{\text {th }}$ February 2020). The minimum value of KLCI is 1219.72 on $34^{\text {th }}$ observation period (19 ${ }^{\text {th }}$ March 2020).

The difference between maximum value and minimum value of KLCI is $-21.54 \%$. Therefore, significant negative value indicates COVID-19 outbreak affected KLCI market price. The economic activity in KLCI market experienced negative effect that slowed down all economic activities during outbreak of COVID-19 pandemic.

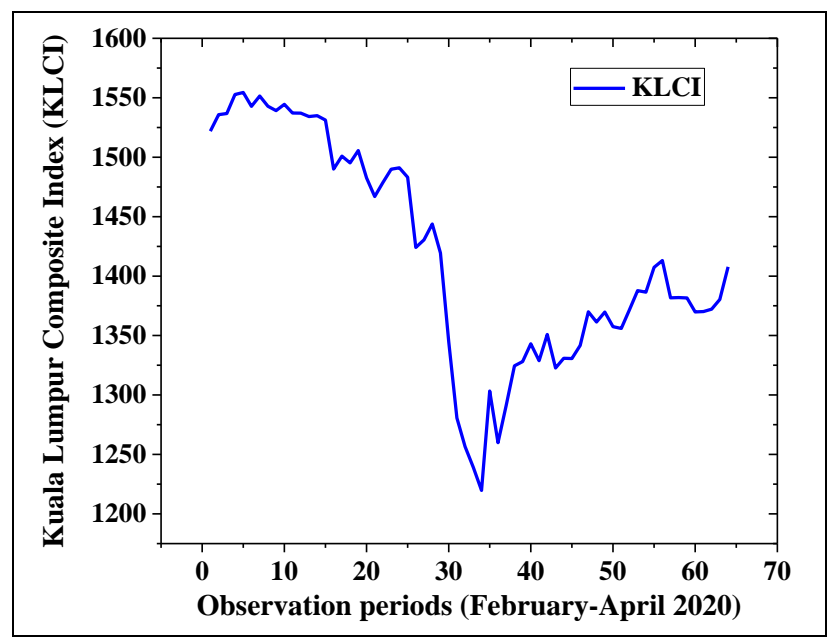

Fig. 2: KLCI movement during COVID-19 outbreak

\section{EFFECT OF COVID-19 TO BANKING SECTOR}

In analyzing the impact of COVID-19 towards banking sectors, this study selected three share prices of banking institutions that listed on FTSE Bursa Malaysia KLCI. Based on the market capitalization, this study selected three main banking companies in Malaysia as the indicator for performance during COVID-19 outbreak.

Figure 3 shows the share price movement for CIMB Bank Berhad. The observation periods started form $3^{\text {rd }}$ February 2020 until 30 ${ }^{\text {th }}$ April 2020. The total number of daily observations are 64 trading days. The first value of share price is value at MYR 4.85 for one unit of share. The value of share price for last observation is MYR 3.45 for one unit of share. The maximum value of share price is MYR 5.15 on $5^{\text {th }}$ observation $\left(7^{\text {th }}\right.$ February 2020$)$. The minimum value of share price is MYR 3.14 on $34^{\text {th }}$ observation $\left(19^{\text {th }}\right.$
March 2020). The percentages between maximum and minimum value was calculate using Equation (1).

$\Delta P=\frac{3.14-5.15}{5.15} \times 100 \%=-39.03 \%$

Equation (1) shows there is significant changes of share price with value of $-39.03 \%$. Therefore, the outbreak of COVID-19 gives impact towards CIMB Bank Berhad.

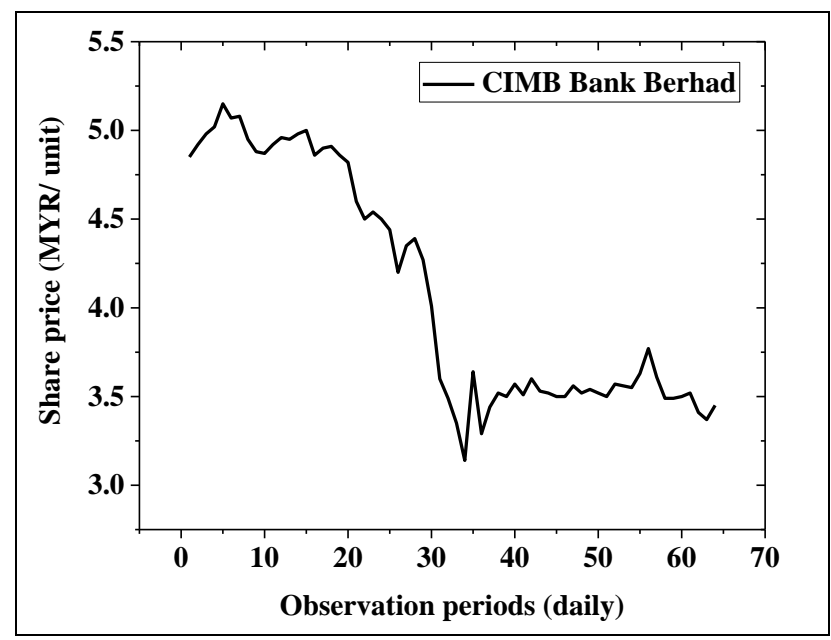

Fig. 3: Share price movement for CIMB Bank Berhad

Next, Figure 4 shows the share price movement for Malayan Banking Berhad. The observation periods started form $3^{\text {rd }}$ February 2020 until $30^{\text {th }}$ April 2020. The total number of daily observations are 64 trading days. The first value of share price is value at MYR 8.36 for one unit of share. The value of share price for last observation is MYR 7.57 for one unit of share. The maximum value of share price is MYR 8.54 on $7^{\text {th }}$ observation $\left(11^{\text {th }}\right.$ February 2020). The minimum value of share price is MYR 7.08 on $34^{\text {th }}$ observation (19 ${ }^{\text {th }}$ March 2020).

The percentages between maximum and minimum value was calculate using Equation (2).

$\Delta P=\frac{7.08-8.54}{8.54} \times 100 \%=-17.10 \%$

Equation (2) shows there is significant changes of share price with value of $-17.10 \%$. Therefore, the outbreak of COVID-19 gives impact towards Malayan Banking Berhad. 


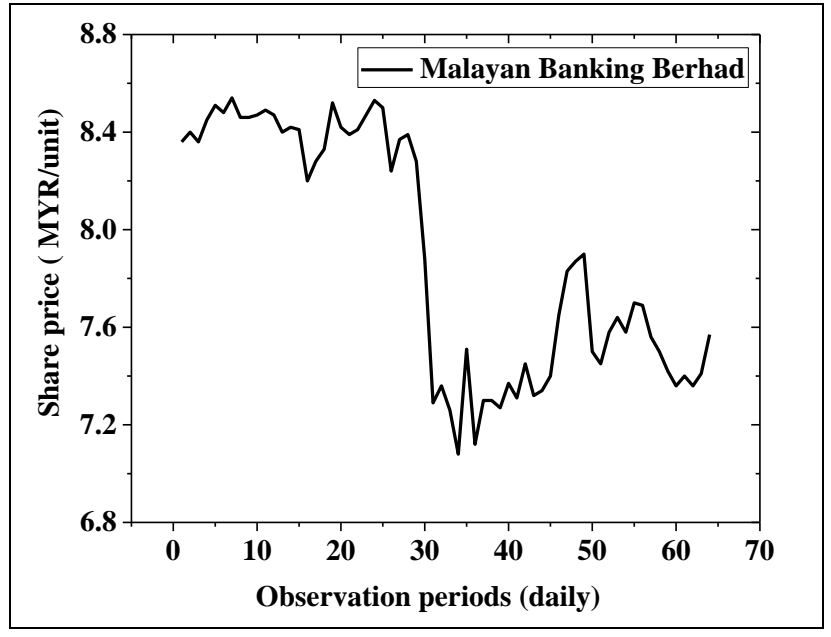

Fig. 4: Share price movement for Malayan Banking Berhad

Then, Figure 5 shows the share price movement for Public Bank Berhad. The observation periods started form $3^{\text {rd }}$ February 2020 until $30^{\text {th }}$ April 2020. The total number of daily observations are 64 trading days. The first value of share price is value at MYR 3.712 for one unit of share. The value of share price for last observation is MYR 3.276 for one unit of share. The maximum value of share price is MYR 3.712 on $1^{\text {st }}$ observation ( $1^{\text {st }}$ February 2020). The minimum value of share price is MYR 2.532 on $25^{\text {th }}$ observation ( $6^{\text {th }}$ March 2020).

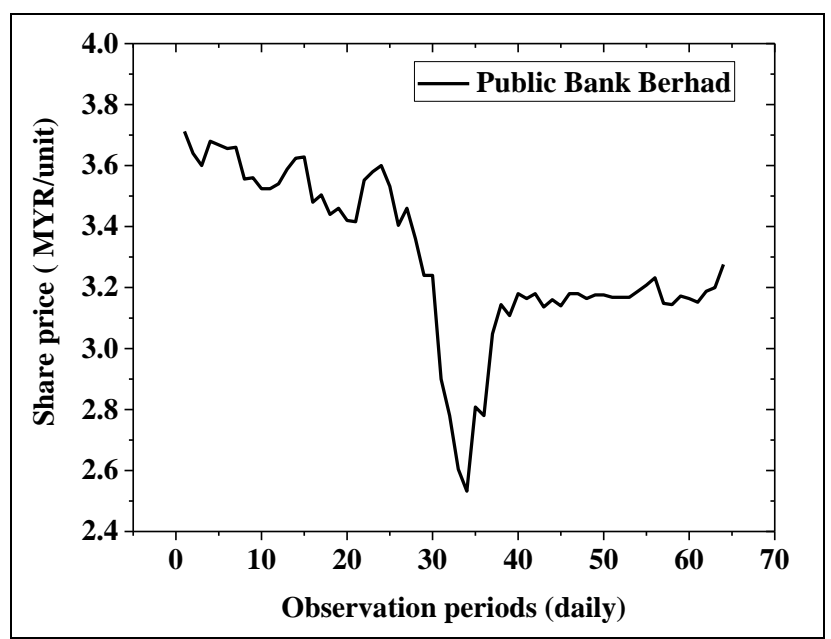

Fig. 5: Share price movement for Public Bank Berhad

The percentages between maximum and minimum value was calculate using Equation (3).

$\Delta P=\frac{2.532-3.712}{3.712} \times 100 \%=-31.79 \%$

Equation (3) shows there is significant changes of share price with value of $-31.79 \%$. Therefore, the outbreak of COVID-19 gives impact towards Public Bank Berhad.

\section{CONCLUSION}

The objective of this research is to evaluate the economic impact of COVID-19 outbreak towards finance and banking industry. This study selected two main market for stock prices namely S\&P 500 and KLCI as market index analysis for assessing economic impact because of COVID-19 outbreak. Meanwhile, for analyzing banking industries, three banking institution in Malaysia were selected to examined the effect of Covid-19 towards finance and banking industry. Main findings of this study are:

(a) First observation of market value S\&P 500 is 3248.92 on $3^{\text {rd }}$ February 2020. The maximum value of market index S\&P 500 is 3386.15 on $12^{\text {th }}$ observation period (19 ${ }^{\text {th }}$ February 2020). The minimum value of S\&P 500 is 2237.40 on $35^{\text {th }}$ observation period $\left(23^{\text {rd }}\right.$ March 2020). The significant drop in S\&P 500 market index indicates COVID-19 outbreak give negative effect towards economic development.

(b) The calculated difference between maximum value and minimum value of market index for KLCI changes is $-21.54 \%$. Therefore, significant negative value indicates COVID-19 outbreak affected KLCI market price. The economic activity in KLCI market experienced negative effect that slowed down all economic activities during outbreak of COVID-19.

(c) First banking institution selected for this study is CIMB Bank Berhad. The maximum value of share price is MYR 5.15 on $5^{\text {th }}$ observation ( $7^{\text {th }}$ February 2020). The minimum value of share price is MYR 3.14 on $34^{\text {th }}$ observation $\left(19^{\text {th }}\right.$ March 2020). There is significant change of calculated share price with value of $-39.03 \%$. Therefore, the outbreak of COVID-19 gives significant impact towards CIMB Bank Berhad.

(d) The second banking institution that evaluated in this study is Malayan Banking Berhad. There is significant change of dynamic share price with value of $-17.10 \%$. Therefore, the outbreak of COVID-19 gives significant impact towards Malayan Banking Berhad.

(e) The third banking institution that selected in this study is Public Bank Berhad. The maximum value of share price is MYR 3.712 on $1^{\text {st }}$ observation $\left(1^{\text {st }}\right.$ February 2020). The minimum value of share price is MYR 2.532 on $25^{\text {th }}$ observation (6 ${ }^{\text {th }}$ March 2020). There is significant change of share price with value of $-31.79 \%$. Therefore, the outbreak of COVID-19 gives impact towards Public Bank Berhad.

The findings of this study give accurate information to 
investors regarding the economic impact because of COVID-19. In the same time, this study gives information for policy makers in designing the optimal interest rate in improving the current economic situation of finance and banking industry during the COVID-19 outbreak. This study also helps society to alert regarding the impact of COVID-19 to their finance and economic activities.

For further study, it is suggested to develop questionnaires in evaluating the customer awareness and perception towards finance and banking industry during the outbreak of COVID-19 pandemic.

\section{ACKNOWLEDGEMENTS}

This work was supported by Universiti Utara Malaysia (UUM) and Universiti Malaysia Perlis (UniMAP) in Malaysia.

\section{REFERENCES}

[1] Abu Bakar, N. and Rosbi, S. (2017a). Robust Diagnostics of Box-Jenkins statistical Method in Forecasting Share Price Performance for Sharia-Compliant Oil and Gas sector in Malaysia Stock Exchange. International Journal of Scientific Research and Management, 5(7), 6364-6376.

[2] Abu Bakar, N. and Rosbi, S. (2017b). Data Clustering Using Autoregressive Integrated Moving Average (ARIMA) Model for Islamic Country Currency: An Econometrics Method for Islamic Financial Engineering. The International Journal of Engineering and Science, 6(6), 22-31.

[3] Abu Bakar, N. and Rosbi, S. (2018a). Efficient Frontier Analysis for Portfolio Investment in Malaysia Stock Market. Science International (Lahore), 30 (5), 723-729.

[4] Abu Bakar, N. and Rosbi, S. (2018b). Evaluation of Risk Reduction for Portfolio in Islamic Investment Using Modern Portfolio Theory. International Journal of Advanced Engineering Research and Science, 5(11), 27- 34.

[5] Abu Bakar, N., Rosbi, S., (2019a). Robust Hybrid Optimization Method to Reduce Investment Portfolio Risk using Fusion of Modern Portfolio Theory and Genetic Algorithm. International Journal of Engineering and Advanced Technology, 8(6S3), 136-148.

[6] Abu Bakar, N. and Rosbi, S. (2019b). New Approach of Calculation for Malaysia Shariah Composite Index. The International Journal of Engineering and Science, 8(3), 5159.

[7] Abu Bakar, N. and Rosbi, S. (2019c). Mathematical Model Composition of Stock Price Composite Index: A Case Study of Malaysia Stock Exchange. International Journal of Advances in Scientific Research and Engineering, 5(3), 5764.

[8] Abu Bakar, N., Rosbi, S., (2019d). Robust Statistical Portfolio Investment in Modern Portfolio Theory: A Case Study of Two Stocks Combination in Kuala Lumpur Stock Exchange. International Journal of Engineering and Advanced Technology, 8(5C), 214-221.
[9] Abu Bakar, N. and Rosbi, S. (2020). Impact of Coronavirus Disease 2019 (COVID-19) to Equity Market and Currency Exchange Rate. IOSR Journal of Economics and Finance, 11(2), 17-26.

[10] Tee, C. M. (2017). Political connections, institutional investors monitoring and stock price synchronicity: Evidence from Malaysian firms. Managerial Finance, 43(11), 1236-1253.

[11] Zainudin, R., Mahdzan, N.S. and Yet, C.H. (2018). Dividend policy and stock price volatility of industrial products firms in Malaysia. International Journal of Emerging Markets, 13(1), 203-217.

[12] Michelfelder, R. A. and Pandya, S. (2005). Volatility of stock returns: emerging and mature markets. Managerial Finance, 31(2), 66-86.

[13] Kighir, A.E., Omar, N.H. and Mohamed, N. (2015). Corporate cash flow and dividends smoothing: a panel data analysis at Bursa Malaysia. Journal of Financial Reporting and Accounting, 13(1), 2-19. 